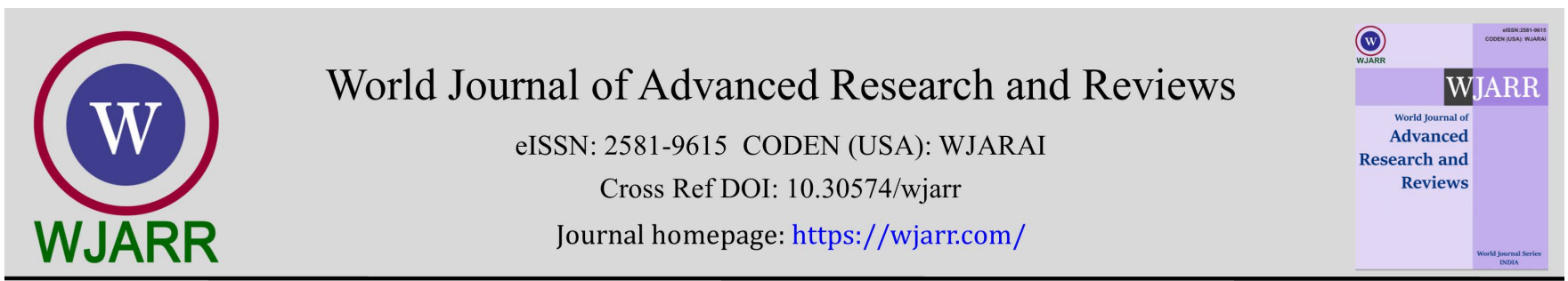

(RESEARCH ARTiClE)

\title{
The impact of organizational culture on public procurement act compliance in Obuasi municipality
}

\author{
Kelvin Gyamfi 1, ${ }^{*}$, Moisob Adamu ${ }^{2}$ and Graham Billa ${ }^{3}$ \\ ${ }^{1}$ Obuasi Municipal Assembly, Kumasi-Ghana/West Africa. \\ ${ }^{2}$ Ahafo Ano South-West District Assembly, Kumasi-Ghana/West Africa. \\ ${ }^{3}$ C.K Tedam University of Technology \& Applied Sciences, Navrongo-Upper East.
}

World Journal of Advanced Research and Reviews, 2021, 12(03), 187-199

Publication history: Received on 25 September 2021; revised on 30 November 2021; accepted on 02 December 2021

Article DOI: https://doi.org/10.30574/wjarr.2021.12.3.0489

\begin{abstract}
Public procurement has become an integral component of Saving Public purse in the whole world wide not exempting Africa and for that matter Ghana. Public procurement compliance is one of the major factors that can lead to major saving in public spending. The major objective of this research work was to appreciate how organizational culture impact on compliance with the Public Procurement Act in the Obuasi Municipality. Largely four objectives were explored to asses and investigate the study in order to draw conclusion. Both Quantitative and qualitative methods were employed to conduct the study. The study made use of 150 participants using a convenient sampling procedure. The study revealed that involvement $(\beta=0.42$, p-value $<0.05)$ was a significant determinants of public procurement compliance Act whiles controlling for habit, stewardship behaviour and media publicity. Moreover, study found that Adaptability $(\beta=0.56$, p-value $<0.05)$ was a significant determinants of public procurement compliance Act whiles controlling for habit, stewardship behaviour and media publicity. Again, study revealed that mission $(\beta=-0.53$, p-value $<0.05$ ) was a significant determinants of public procurement compliance Act whiles controlling for habit, stewardship behaviour and media publicity. However, the study found that consistency $(\beta=-0.13, p$-value $>0.05)$ was not a significant determinants of public procurement compliance Act whiles controlling for habit, stewardship behaviour and media publicity. The study concludes that organizational is a determinant of procurement Act compliance meanwhile socio-economic variables significantly predicts procurement compliance. The study recommends improvement in cultural practices in public institutions to enhance compliance with the Procurement Act.
\end{abstract}

Keywords: Organization; Procurement; Culture; Compliance; Consistency; Adaptability

\section{Introduction}

Organizational culture establishes the unwritten norms and regulations that regulate conduct. [32] defines organizational culture as a set of values, norms, beliefs, attitudes, and concerns that may or may not be articulated but influence how employees act and complete tasks. It's what's crucial when it comes to how people and things act.

Organizational culture may also be defined as the distinctive conformance to norms, values, beliefs, and even ways of behaving that explain how groups and individuals work together to accomplish goals [52]. When new workers are employed, they are given an orientation to the company's culture, which helps them get acquainted with the company's activities [18]. Organizational culture, according to [62], is the persistent force and natural developing living system that injects structure and stability into any organization, particularly in the network of human interactions and activities. A system of common meanings held by members of an organization that differentiates them from others is referred to as organizational culture [2].

\footnotetext{
* Corresponding author: Kelvin Gyamfi

Local Government Service of Ghana, Box MB 396, Ministries-Accra.
} 
[49] was enacted in Ghana to standardize government procurement processes. The Act aims to make sure that public funds are spent properly, economically, and effectively. It makes public procurement fair, transparent, and nondiscriminatory. Public procurement accounts for 50-70 percent of national budgets (after personal emoluments), 14 percent of GDP, and 24 percent of imports in Ghana. As a result, public procurement has both social and economic implications for the country [64].

According to [54] sources, public procurement took occurred between 2400 and 2800 B.C. The culture of an organization, whether public or private, determines its procurement procedures and practices. According to the United Nations, public procurement is defined as "the overall process of acquiring goods, civil works, and services," which includes all functions from identifying needs to selecting and soliciting sources, preparing and awarding contracts, and all phases of contract administration through the end of a service contract or asset's useful life [10]

Procurement standards and regulations are strict, which stymies procurement processes. Despite the fact that the corporation has a green policy in place, its implementation is constrained by corporate culture and fiscal restrictions. The long-term cost of ownership is not factored into procurement planning, and the organization has no long-term procurement strategy [50]. [11], looked into the factors that influence compliance with procurement laws. According to the study, organizational culture, external agency enforcement, staff training, and procurement procedures all influence procurement regulation compliance in the public sector. Procurement skills, enforcement, organizational procurement culture, and acquaintance with procurement legislation are all factors that influence PPDA implementation in public institutions, according to [15]. The study was based on the following research questions: What are the Organizational cultural practices in Obuasi Municipality, as well as what are the Public Procurement Act Compliance practices in Obuasi Municipality, and finally what are the effect of Organizational Culture on Public Procurement Compliance in Obuasi Municipality?

The study's major goal is to evaluate the link between an organization's culture and compliance with the Public Procurement Act in the Obuasi Municipality.

\section{Problem Statement}

In the literature and adhering to the Public Procurement Act had not been adequately recorded. In the case of private firms, the majority of these past research focused on procurement act compliance and performance or profitability. The influence of organizational culture on procurement act compliance had not been thoroughly investigated [50]; [30].

Organizational culture has a bigger impact on organizational growth, establishing a precedence for future methods. Every facet of corporate culture is considered a key environmental factor that influences the system and its subsystems. Organizational culture is a set of fundamental assumptions shared by all employees. [44] investigated the extent to which local governments complied with procurement laws, as well as the role of media attention in enforcing compliance with the Government Procurement law. According to the study, local government procurement compliance with the state procurement statute is quite low.

Ghana's public sector needs to bridge the knowledge gap using empirical data. The impact of firm cultural practices on compliance with the Public Procurement Act requires a new study. The goal of this research is to see if there is a link between corporate culture and compliance with the Public Procurement Act.

\section{Literature}

Organizational culture may be classified in four ways, according to [14] model: mission, flexibility, involvement, and consistency. To each of these main dimensions, the following three sub-dimensions are added:

- Mission - Strategic Direction and Intent, Goals and Objectives and Vision

- Adaptability - Creating Change, Customer Focus and Organizational Learning

- Involvement - Empowerment, Team Orientation and Capability Development

- Consistency - Core Values, Agreement, Coordination/Integration

Denison's approach also allows for broad classifications such as internationally or internally focused, as well as fluid vs stable cultures. The approach has traditionally been used to diagnose organizational cultural issues. 
Organizational culture, according to [52], is defined as "something learnt by a group of individuals with the intense goal of addressing problems both outwardly and internally." These taught items are able to achieve the group's goal, therefore they are seen as genuine and are regarded by new followers as the proper way they perceive, think, and feel about those difficulties.

The cooperation of ideas among employees of an organization's culture causes them to defer from other connected organizations. Organizational culture, according to [62], refers to the existing forces and natural emitting systems that cast order and stability in any organization, particularly when it comes to the organizational network of human transactions and activities.

Public procurement, in general, refers to the method through which the government purchases goods and services. Public procurement includes the purchase of commodities and the contracting of building works and services from state budgets, local authority budgets, state foundation funds, state-guaranteed domestic or international loans, foreign aid, and procurement by a purchasing organization utilizing public funds [31]. The concept of public procurement has been handled in a variety of ways by various authors, scholars, and institutions. The United Nations defines procurement as "all methods of acquiring goods, professional works, and services, which includes all functions ranging from identifying needs to selecting and soliciting sources, contract preparation and award, and all phases of contract administration through the end of a service contract or the useful life of an asset" [59].

Professionalism in public procurement refers to the workforce's educational level and qualifications, as well as a professional attitude to purchasing tasks. If the workforce is not properly trained in procurement, severe penalties, including violations of codes of behavior, will be imposed [50]. Cheating occurs as a result of a lack of professionalism in public procurement, which impedes compliance. Procurement compliance in Public Procurement can be assessed through habit, stewardship behavior and media publicity.

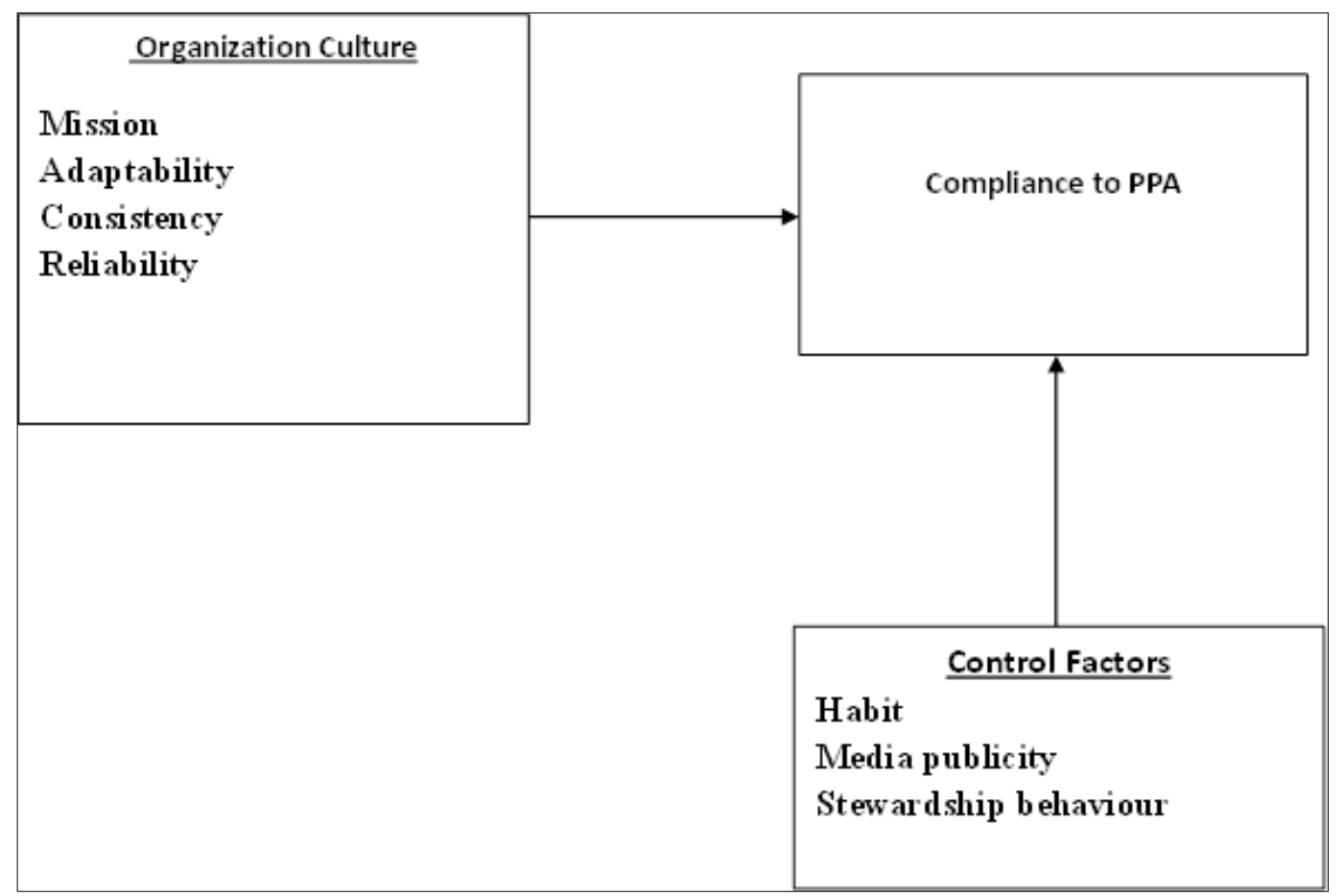

Figure 1 Conceptual Framework

This framework is provided based on the theories discussed in the preceding parts. This research is founded on the idea that corporate culture has an impact on compliance with the Public Procurement Act. The research goes on to say that organizational cultural qualities including consistency, involvement, adaptability, and mission will have an impact on compliance with the Public Procurement Act. Previous research has shown that there is a link between the two. [57], for example, attempted to conceptualize the antecedents and effects of compliance and non-compliance behavior in public procurement. The research went on to say that factors including media coverage, moral duty, social influence, and familiarity will all play a role in predicting compliance with the Public Procurement Act. 


\section{Methodology}

\subsection{Research Design}

This study employed a positivist ontology and a quantitative research approach. Research design is the framework and structure of an investigation established with the purpose of getting answers to research questions. In this study, descriptive and explanatory research designs were utilized. It's also been labeled as a quantitative technique. The purpose of the study was to see if there was a relationship between corporate culture and adherence to the Public Procurement Act. The goal of the study was to use numerical data to assess the influence of corporate culture on public procurement. Journal of Economic Policy Research published the study's findings.

\subsection{Population of the Study}

The research population included all members of the Obuasi Municipality's staff and management, with an emphasis on the Municipal Assemblies. The study's target group was personnel who were involved in all aspects of procurement.

\subsection{Sample technique and Sample size}

This study used a sample size of 150 participants. Convenience sampling approaches were used in this study. The goal of most investigations is to learn more about a group of people. Even if the replies were not regularly distributed, the researchers discovered no statistical issues.

\subsection{Data collection Instrument}

The questionnaire was utilized by the researchers to collect the essential data for the study. To meet some of the research objectives, the questionnaire used a Likert scale ranging from 1 to 5 (strongly disagree to agree). It was chosen to provide respondents with the option of answering the questions whenever they wanted. The interview guide, on the other hand, was employed to collect data that the questionnaire couldn't.

\subsection{Reliability and Validity Instruments}

The degree of consistency with which a questionnaire evaluates the attribute it is supposed to test can be used to determine its reliability. The researcher was the only one who administered the questions, which reduced bias, as well as standardizing conditions like friendliness and support. Validity of instrument, on the other hand, is the degree at which it measures what it is supposed to measure. Most of the respondents completed the questionnaires to aid ease interpretation and discussions.

\section{Discussions}

This section deals with the data collected from the questionnaires administered to the various respondents. Analyses were made from the data collected and subsequently discussions were made in line with the supported literature.

\subsection{Data response}

The study gathered information from 150 people working in the local government sector of Ghana, specifically Obuasi Municipality. The demographic information of the respondents was gathered and evaluated in the diagrams below.

\subsection{Level of Education}

The figure 4.3 presents respondents educational level. $69.3 \%$ of the respondents have completed their first degree, $14.7 \%$ were those with their Master's degree, $10.7 \%$ have professional certificates and $5.3 \%$ were secondary school graduates.

\subsection{Public Procurement Act Compliance}

Table 1 presents the descriptive statistics on Public Procurement Act Compliance. The study revealed that majority $(M=4.49, S D=0.66)$ of the respondent belief their institution have adequately defined procurement plan. Most of the respondents $(\mathrm{M}=4.12, \mathrm{SD}=0.77)$ accepted that advertisement tender invitation on National Daily and sending information for placement in Public Procurement Bulletin. A greater number of the respondents $(\mathrm{M}=4.17, \mathrm{SD}=0.89)$ affirmed that their institution have secured tender box in place and tender opening register. Also, majority of the respondents $(M=4.44, S D=0.68)$ agreed that their institution keep minutes of bid opening including all opening records with a greater proportion of the respondents $(\mathrm{M}=4.32, \mathrm{SD}=0.81)$ belief that they conduct evaluate tenders in accordance 
with tendering requirements and lastly, most of the respondents $(M=4.15, S D=0.89)$ agreed that they notify winners of contract and unsuccessful tenderers.

Table 1 Public Procurement Act Compliance

\begin{tabular}{|l|c|c|c|c|}
\hline \multicolumn{1}{|c|}{ Statements } & Minimum & Maximum & Mean & Std. D \\
\hline $\begin{array}{l}\text { Having an adequately defined } \\
\text { procurement plan }\end{array}$ & 2.00 & 5.00 & 4.49 & 0.66 \\
\hline $\begin{array}{l}\text { Advertising tender invitation on } \\
\text { National Daily and Sending information } \\
\text { for placement in Public Procurement } \\
\text { Bulletin }\end{array}$ & 1.00 & 5.00 & 4.12 & 0.77 \\
\hline $\begin{array}{l}\text { Having secured tender box in place and } \\
\text { tender opening register }\end{array}$ & 1.00 & 5.00 & 4.17 & 0.89 \\
\hline $\begin{array}{l}\text { Keeping minutes of bid opening } \\
\text { including all opening records }\end{array}$ & 1.00 & 5.00 & 4.44 & 0.68 \\
\hline $\begin{array}{l}\text { Evaluating tenders in accordance with } \\
\text { tendering }\end{array}$ & 1.00 & 5.00 & 4.32 & 0.81 \\
\hline $\begin{array}{l}\text { Notifying Winner of Contract and } \\
\text { unsuccessful tenderers requirements }\end{array}$ & 1.00 & 5.00 & 4.15 & 0.89 \\
\hline
\end{tabular}

Source: Field Data (2021)

\subsection{Organizational Culture}

Table 2 presents the descriptive statistics on assessment of organizational culture. The study showed the results as follows; most of the respondents $(M=3.29, \mathrm{SD}=1.19)$ indicated that the authority's initiative and ability to manage their own work creates a sense of ownership and responsibility. Also, majority of the respondents $(M=3.65, S D=1.13)$ stated that team effort is essential through working cooperatively to achieve common goals and committing to mutual accountability. Moreover, a number of the respondents $(M=3.71, S D=1.08)$ indicated that organizational roles and functions are clearly defined through effective synergies and controls to achieve common goals and avoid role conflict. Again, majority of the respondents $(M=3.66, S D=0.94)$ agreed that decision-making on critical issues of the organization is reached through dialogue and consensus. More so, a greater proportion of the respondents $(M=3.73, S D=0.89)$ stated that members of the organization are committed to a set of principles, values and expectation, which they strive to achieve. A greater proportion of respondents $(M=3.67, \mathrm{SD}=0.97)$ showed that the organization's ability to adapt and develop capacities to meet modern and changing trends with majority $(M=3.42, S D=0.89)$ stating that signals from the environment are effectively interpreted and opportunities derived to encourage innovation, knowledge acquisition and capacity building. Most of the respondents $(M=3.65, S D=0.89)$ accepted that strategic intentions and purposes of the organization are clearly conveyed to stakeholders with a reasonable number of respondents $(3.52, \mathrm{SD}=0.93)$ agreed that the mission of the organization provides a clear direction to all stakeholders and lastly, majority of the respondents $(M=3.51, S D=1.00)$ stated that the organization has a shared view and future goals to which all members aspire to achieve through effective supervision, guidance and direction.

\subsection{Influencers of Compliance}

Table 3 presents the results on the influencers of compliance. From the table, majority of the respondents (M=3.91, $\mathrm{SD}=1.27$ ) agreed that publication of the tender in the media help increase transparency and participation of the public in Local Government Procurement, most of the respondents $(M=3.30, S D=1.15)$ agreed that the media in Ghana report the act of corruption and fraud are highly involved in the coverage of government procurement. Moreover, a greater number of the respondents $(M=3.06, S D=1.13)$ belief that the Ghanaian media sector is highly politicized and therefore cannot be totally relied on in respect of government procurement and majority of the respondents $(M=3.44, S D=1.20)$ indicated that complying with public procurement act is what they frequently do. Also, majority of the respondents $(\mathrm{M}=3.31, \mathrm{SD}=1.08)$ agreed that complying with tendering procedure have been a regular practice and a greater proportion of the respondents $(\mathrm{M}=3.39, \mathrm{SD}=1.05)$ indicated that complying with public procurement manuals and regulations policies is a routine practice. A number of the respondents $(M=3.77, S D=1.13)$ affirmed that training programmes in place for procurement practitioners. Moving on, a number of the respondents $(M=3.85, S D=1.13)$ belief they have staffs with professional procurement qualification with many of the respondents $(M=3.66, S D=0.93)$ indicated 
that they evaluate the performance of procurement staffs. In addition, majority ( $M=3.69, \mathrm{SD}=0.96)$ of the respondents agreed that they have quality control mechanism in place with most of the respondents $(M=3.72, S D=0.96)$ stated that they have anti-corruption measures in place and lastly, a greater number of respondents $(M=3.65, S D=0.98)$ agreed that fairness and transparency in resolution of cases within the terms established in the legal framework.

\subsection{Test of Validity and Reliability}

The extracted constructs were assessed to ascertain their validity and reliability by conducting the relevant tests. The reliability of the constructs was analyzed by assessing the internal consistency of each construct. Internal consistency of each construct was assessed by conducting Cronbach Alpha tests. The rule of thumb is that Cronbach Alpha values for each construct should be a minimum of 0.7 [24]. A look at the Cronbach Alpha values for each construct reveals that Cronbach Alpha values ranged from 0.747 to 0.912 , confirming internal consistency of the constructs. The Cronbach Alpha for Moral Behaviour could not be computed because there was only one item remaining for the construct after EFA and CFA had been conducted. The full details of the Cronbach Alpha results are presented in Table 2 below.

Table 2 Internal consistency of constructs

\begin{tabular}{|l|c|c|}
\hline Construct & Number of items & Cronbach Alpha \\
\hline Involvement & 2 & 0.873 \\
\hline Consistency & 3 & 0.912 \\
\hline Adaptability & 2 & 0.764 \\
\hline Mission & 2 & 0.795 \\
\hline PPCA & 5 & 0.842 \\
\hline Habit & 3 & 0.898 \\
\hline Stewardship Behaviour & 6 & 0.747 \\
\hline Media Publicity & 3 & 0.834 \\
\hline
\end{tabular}

The item loadings and cross-loadings can be used to determine the validity of the study items. As mentioned in the previous section and shown in Table 5, all retained items have high loadings (more than 0.7 ) and do not cross-load considerably on other things.

\subsection{Multiple Regression Analysis}

\subsubsection{Model Fitness Tests}

Table 3 Model Fitness

\begin{tabular}{|c|c|c|c|c|c|}
\hline Model & R Square & R Square Changes & DF & F-Statistics & P-value \\
\hline 1 & 0.065 & 0.065 & 4 & 2.468 & 0.048 \\
\hline 2 & 0.069 & 0.004 & 5 & 2.077 & 0.072 \\
\hline 3 & 0.105 & 0.035 & 6 & 2.704 & 0.016 \\
\hline 4 & 0.154 & 0.0 .50 & 7 & 3.590 & 0.001 \\
\hline
\end{tabular}

There are four proposed and tested models in this study using hierarchical linear regression involving dimensions of organizational culture and public procurement compliance Act whiles controlling for habit, stewardship behaviour and media publicity. From study reveals significant model fit (F-Statistics $=2.47, p$-value $0.05<0.5$ ) for model one (1) that is involvement explains $6.5 \%$ of variations in public procurement compliance Act whiles controlling for habit, stewardship behaviour and media publicity. Again, study finds a significant model fit (F-Statistics= $2.08, p$-value $0.05<0.5$ ) for model two (2) that is consistency explains $6.9 \%$ of variations in public procurement compliance Act whiles controlling for habit, stewardship behaviour and media publicity. Moreover, study finds a significant model fit (F-Statistics= 2.70, $p$ - 
value $0.05<0.5$ ) for model three (3) that is adaptability explains $10.5 \%$ of variations in public procurement compliance Act whiles controlling for habit, stewardship behaviour and media publicity. Finally, study finds a significant model fit (F-Statistics $=2.70, p$-value $0.05<0.5$ ) for model four (4) that is mission explains $15.4 \%$ of variations in public procurement compliance Act whiles controlling for habit, stewardship behaviour and media publicity.

\section{Results of the Hierarchical Regression}

The Table below presents the multiple regression results. The study reveals that involvement $(\beta=0.42, p$-value $<0.05)$ is a significant determinants of public procurement compliance Act whiles controlling for habit, stewardship behaviour and media publicity. This implies that holding all other factors constant at zero, a change in involvement will bring $42 \%$ change in of public procurement compliance Act whiles controlling for habit for habit, stewardship behaviour and media publicity. The $\mathrm{H}_{1}$ : involvement has significant effect on public procurement compliance Act whiles controlling for habit, stewardship behaviour and media publicity. Therefore $\mathrm{H} 1$ is accepted - thus involvement has significant effect on public procurement compliance Act.

Moreover, study reveals that Adaptability $(\beta=0.56, p$-value $<0.05)$ is a significant determinants of public procurement compliance Act whiles controlling for habit, stewardship behaviour and media publicity. This implies that holding all other factors constant at zero, a change in adaptability will bring $56 \%$ change in of public procurement compliance Act whiles controlling for habit for habit, stewardship behaviour and media publicity. The $\mathrm{H}_{3}$ : adaptability has significant effect on public procurement compliance Act whiles controlling for habit, stewardship behaviour and media publicity. Therefore $\mathrm{H} 3$ is accepted - thus adaptability has significant effect on public procurement compliance Act.

Again, study reveals that mission $(\beta=-0.53, p$-value $<0.05)$ is a significant determinants of public procurement compliance Act whiles controlling for habit, stewardship behaviour and media publicity. This implies that holding all other factors constant at zero, a change in mission will bring $-53 \%$ change in of public procurement compliance Act whiles controlling for habit for habit, stewardship behaviour and media publicity. The $\mathrm{H}_{4}$ : mission has significant effect on public procurement compliance Act whiles controlling for habit, stewardship behaviour and media publicity. Therefore $\mathrm{H} 2$ is accepted - thus mission has significant effect on public procurement compliance Act.

However, the study finds that consistency $(\beta=-0.13, p$-value $>0.05)$ is not a significant determinants of public procurement compliance Act whiles controlling for habit, stewardship behaviour and media publicity. The $\mathrm{H}_{2}$ : states that consistency has significant effect on public procurement compliance Act whiles controlling for habit, stewardship behaviour and media publicity. Therefore H4 is rejected - thus consistency has no significant effect on public procurement compliance Act.

Table 4 Hierarchical Regression Results

\begin{tabular}{|c|c|c|c|c|c|}
\hline & \multicolumn{2}{|c|}{ Unstandardized Coefficients } & \multirow{2}{*}{$\frac{\text { Standardized Coefficients }}{\text { Beta }}$} & \multirow[b]{2}{*}{ T-value } & \multirow[b]{2}{*}{ P-value } \\
\hline & B & Std. Error & & & \\
\hline \multicolumn{6}{|l|}{ Model 1} \\
\hline (Constant) & 23.19 & 1.28 & & 18.090 & 0.000 \\
\hline Media Publicity & -0.20 & 0.13 & -0.18 & -1.516 & 0.132 \\
\hline Habit & -0.12 & 0.12 & -0.11 & -1.013 & 0.313 \\
\hline Stewardship Behaviour & 0.12 & 0.07 & 0.18 & 1.633 & 0.105 \\
\hline Involvement & 0.42 & 0.17 & 0.27 & 2.448 & 0.016 \\
\hline \multicolumn{6}{|l|}{ Model 2} \\
\hline (Constant) & 23.74 & 1.48 & & 16.02 & 0.00 \\
\hline Media Publicity & -0.21 & 0.13 & -0.19 & -1.59 & 0.11 \\
\hline Habit & -0.13 & 0.12 & -0.12 & -1.09 & 0.28 \\
\hline Stewardship Behaviour & 0.13 & 0.08 & 0.20 & 1.74 & 0.08 \\
\hline Involvement & 0.54 & 0.24 & 0.35 & 2.27 & 0.03 \\
\hline
\end{tabular}




\begin{tabular}{|c|c|c|c|c|c|}
\hline Consistency & -0.13 & 0.17 & -0.09 & -0.74 & 0.46 \\
\hline \multicolumn{6}{|l|}{ Model 3} \\
\hline (Constant) & 23.22 & 1.48 & & 15.73 & 0.000 \\
\hline Media Publicity & -0.14 & 0.13 & -0.13 & -1.05 & 0.297 \\
\hline Habit & -0.14 & 0.12 & -0.13 & -1.17 & 0.243 \\
\hline Stewardship Behaviour & 0.08 & 0.08 & 0.12 & 1.06 & 0.292 \\
\hline Involvement & 0.40 & 0.24 & 0.26 & 1.66 & 0.099 \\
\hline Consistency & -0.31 & 0.19 & -0.24 & -1.63 & 0.101 \\
\hline Adaptability & 0.56 & 0.24 & 0.30 & 2.35 & 0.020 \\
\hline \multicolumn{6}{|l|}{ Model 4} \\
\hline (Constant) & 23.57 & 1.45 & & 16.31 & 0.000 \\
\hline Media Publicity & -0.08 & 0.13 & -0.07 & -0.62 & 0.539 \\
\hline Habit & -0.14 & 0.11 & -0.14 & -1.26 & 0.208 \\
\hline Stewardship Behaviour & 0.12 & 0.08 & 0.17 & 1.50 & 0.136 \\
\hline Involvement & 0.46 & 0.24 & 0.29 & 1.93 & 0.055 \\
\hline Consistency & -0.07 & 0.20 & -0.06 & -0.36 & 0.722 \\
\hline Adaptability & 0.71 & 0.24 & 0.37 & 2.96 & 0.004 \\
\hline Mission & -0.53 & 0.19 & -0.40 & -2.84 & 0.005 \\
\hline
\end{tabular}

\subsection{Hypotheses Testing}

The four main hypotheses the of the study are presented in the table below. All these hypotheses are tested at 0.05 error term and confidence interval.

Table 5 Hypotheses Testing

\begin{tabular}{|l|l|l|l|}
\hline \multicolumn{1}{|c|}{ Hypothesis } & Model & Results & Remarks \\
\hline $\begin{array}{l}\text { H1: involvement has significant effect on public } \\
\text { procurement compliance Act whiles controlling for } \\
\text { habit, stewardship behaviour and media publicity }\end{array}$ & Model 1 & Significant & Accepted \\
\hline $\begin{array}{l}\text { H2: consistency has significant effect on public } \\
\text { procurement compliance Act whiles controlling for } \\
\text { habit, stewardship behaviour and media publicity }\end{array}$ & Model 2 & Significant & Accepted \\
\hline $\begin{array}{l}\text { H3: Adaptability has significant effect on public } \\
\text { procurement compliance Act whiles controlling for } \\
\text { habit, stewardship behaviour and media publicity }\end{array}$ & Model 3 & Insignificant & Rejected \\
\hline $\begin{array}{l}\text { H4: Mission has significant effect on public } \\
\text { procurement compliance Act whiles controlling for } \\
\text { habit, stewardship behaviour and media publicity }\end{array}$ & Model 4 & Significant & Accepted \\
\hline
\end{tabular}

Source: Field Data, 2021

\section{Discussion}

This study is based on the assumption that organizational cultural have effect on public procurement Act compliance. More specifically the study proposes that organizational cultural traits such as Consistency, Involvement, Adaptability and Mission will effect compliance of public procurement Act. The study reveals that involvement $(\beta=0.42, p$-value $<$ 
0.05) is a significant determinants of public procurement compliance Act whiles controlling for habit, stewardship behaviour and media publicity. The $\mathrm{H}_{1}$ : involvement has significant effect on public procurement compliance Act whiles controlling for habit, stewardship behaviour and media publicity. Therefore H1 is accepted - thus involvement has significant effect on public procurement compliance Act. Moreover, study reveals that Adaptability $(\beta=0.56, p$-value $<$ 0.05 ) is a significant determinants of public procurement compliance Act whiles controlling for habit, stewardship behaviour and media publicity. The $\mathrm{H}_{3}$ : adaptability has significant effect on public procurement compliance Act whiles controlling for habit, stewardship behaviour and media publicity. Therefore H3 is accepted - thus adaptability has significant effect on public procurement compliance Act. Again, study reveals that mission $(\beta=-0.53, p$-value $<0.05)$ is a significant determinants of public procurement compliance Act whiles controlling for habit, stewardship behaviour and media publicity. The $\mathrm{H}_{4}$ : mission has significant effect on public procurement compliance Act whiles controlling for habit, stewardship behaviour and media publicity. Therefore $\mathrm{H} 4$ is accepted - thus mission has significant effect on public procurement compliance Act. However, the study finds that consistency $(\beta=-0.13, p$-value $>0.05)$ is not a significant determinants of public procurement compliance Act whiles controlling for habit, stewardship behaviour and media publicity. The $\mathrm{H}_{2}$ : states that consistency has significant effect on public procurement compliance Act whiles controlling for habit, stewardship behaviour and media publicity. Therefore $\mathrm{H} 2$ is rejected - thus consistency has no significant effect on public procurement compliance Act. Thus it is concluded that organizational culture does not predict compliance to public procurement planning practices. This relationship is supported by previous such as Tukamubabwa (2015). Moreover, the study conceptualized that construct such as media publicity, moral obligation, social influence, familiarity will influence significantly predict compliance to public procurement Act. The study revealed that the four independent variables significantly accounted for variation in Compliance to Tender Evaluation and Award practices ( $\mathrm{p}<0.05)$. Specifically, Social Influence (SI) had a positive and statistically significant effect on Tender Evaluation and Award Compliance $(\beta=0.244, t=2.565, p<0.05)$. Interestingly, Moral Behaviour (MB) had a negative and statistically significant effect on Compliance to Tender Evaluation and Award (PTEA) $(\beta=-0.211, t=-$ $2.394, \mathrm{p}<0.05$ ), a result which was not expected. Employee Habit (EH) and Illegal Behaviour (IB) however did not have significant effects on Compliance to Tender Evaluation and Award practices. The amount of variation explained by the independent variables was still low at .071. This relationship is mutually supported. For instance Zubcic and Sims (2011) asserted that media plays a vital role in corporate compliance. The corporate society is made aware of the regulatory outcomes it's evident that wide publication of tenders in the media could help reduce corruption by increasing transparency and participation, thereby promoting public procurement compliance.

\section{Summary of Findings}

\subsection{Public Procurement Act Compliance}

The study found that majority of the respondent's belief their institution have adequately defined procurement plan. Most of the respondents accepted that advertisement for tender invitation on National Daily and sending information for placement in Public Procurement Bulletin brings about fairness. A greater number of the respondents affirmed that their institution have secured tender box in place and tender opening register. Also, majority of the respondents agreed that their institution keep minutes of bid openings including all opening records with a greater proportion of the respondents' belief that they conduct evaluation of tenders in accordance with tendering requirements and lastly, most of the respondents agreed that they notify winners of contract and unsuccessful tenderers.

\subsection{Assessment of Organizational Culture}

The study further found that the authority's initiative and ability to manage their own work creates a sense of ownership and responsibility, team effort is essential through working cooperatively to achieve common goals and committing to mutual accountability, roles and functions are clearly defined through effective synergies and controls to achieve common goals and avoid role conflict, decision-making on critical issues of the organization is reached through dialogue and consensus. More so, a greater proportion of the respondents stated that members of the organization are committed to a set of principles, values and expectations, which they strive to achieve, the organization's ability to adapt and develop capacities to meet modern and changing trends with majority stating that signals from the environment are effectively interpreted and opportunities derived to encourage innovation, knowledge acquisition and capacity building. Most of the respondents accepted that strategic intentions and purposes of the organization are clearly conveyed to stakeholders with a reasonable number of respondents agreed that the mission of the organization provides a clear direction to all stakeholders and lastly, majority of the respondents stated that the organization has a shared view and future goals to which all members aspire to achieve through effective supervision, guidance and direction. 


\subsection{Influence of Compliance}

The study discovered that majority of the respondents agreed that publication of the tender in the media help increase transparency and participation of the public in Local Government Procurement, most of the respondents agreed that the media in Ghana report the act of corruption and fraud are highly involved in the coverage of government procurement, the Ghanaian media sector is highly politicized and therefore cannot be totally relied on in respect of government procurement and majority indicated that complying with public procurement act is what they frequently do. Also, majority agreed that complying with tendering procedure have been a regular practice and a greater proportion indicated that complying with public procurement manuals and regulations policies is a routine practice. A number of the respondents affirmed that training programmes in place for procurement practitioners. Moving on, a number of the respondents belief they have staffs with professional procurement qualification, they evaluate the performance of procurement staffs, they also have quality control mechanism in place with most of the respondents stated that they have anti-corruption measures in place and lastly, a greater number of respondents agreed that fairness and transparency in resolution of cases within the terms established in the legal framework.

\section{Conclusion}

The main purpose of this study was to determine the effect of organizational culture on Public Procurement Act Compliance in the Obuasi Municipality. The study reveals that involvement $(\beta=0.42, p$-value $<0.05)$ is a significant determinants of public procurement compliance Act whiles controlling for habit, stewardship behaviour and media publicity. The $\mathrm{H}_{1}$ : involvement has significant effect on public procurement compliance Act whiles controlling for habit, stewardship behaviour and media publicity. Therefore $\mathrm{H} 1$ is accepted - thus involvement has significant effect on public procurement compliance Act. Moreover, study reveals that Adaptability $(\beta=0.56, p$-value $<0.05)$ is a significant determinants of public procurement compliance Act whiles controlling for habit, stewardship behaviour and media publicity. The $\mathrm{H}_{3}$ : adaptability has significant effect on public procurement compliance Act whiles controlling for habit, stewardship behaviour and media publicity. Therefore $\mathrm{H} 3$ is accepted - thus adaptability has significant effect on public procurement compliance Act. Again, study reveals that mission $(\beta=-0.53, p$-value $<0.05)$ is a significant determinants of public procurement compliance Act whiles controlling for habit, stewardship behaviour and media publicity. The $\mathrm{H}_{4}$ : mission has significant effect on public procurement compliance Act whiles controlling for habit, stewardship behaviour and media publicity. Therefore $\mathrm{H} 4$ is accepted - thus mission has significant effect on public procurement compliance Act. However, the study finds that consistency $(\beta=-0.13, p$-value $>0.05)$ is not a significant determinants of public procurement compliance Act whiles controlling for habit, stewardship behaviour and media publicity. The $\mathrm{H}_{2}$ : states that consistency has significant effect on public procurement compliance Act whiles controlling for habit, stewardship behaviour and media publicity. Therefore $\mathrm{H} 2$ is rejected - thus consistency has no significant effect on public procurement compliance Act.

\section{Compliance with ethical standards}

\section{Acknowledgments}

We would like to extend appreciation to the Business School lecturers at the Ghana Institute of Management and Public Administration (GIMPA), particularly Professor Samuel Famiyeh (Senior Lecturer), as well as the various schools that were involved in the study.

\section{Disclosure of conflict of interest}

All of the authors certify that they have no potential conflicts of interest.

\section{References}

[1] Abere OD, Muturi W. Factors affecting compliance with public procurement and disposal regulations in Kenya. International Journal of Economics, Commerce and Management. 2015; III(11): 1060-1089.

[2] Abu-Jarad IY, Yusof N, Nikbin D. A Review Paper On Organizational Culture And Organizational Performance. International Journal Of Business. 2010.

[3] Alvesson M. Understanding organizational culture. Books.google.com. 2012.

[4] Akuffo MK. Assessing the Level Of Compliance With the Public Procurement Act 2003,(Act 663) In Selected Public Entities In Upper Denkyira East Municipality, Central Region. 2014. 
[5] Ansah SA. Assessment of the Ghana integrated financial management information system (GIFMIS) in public sector procurement in Ghana. Dspace.knust.edu.gh. 2015.

[6] Arrowsmith S. Public Procurement: Basic Concepts and the Coverage of Procurement Rules. Chapter in Public Procurement Regulation: An Introduction (Arrowsmith, S. ed.). 2011; 1-32.

[7] Asare EN, Prempeh KB. Measures of Ensuring Value for Money In Public Procurement: A Case Of Selected Polytechnics In Ghana. Journal of Logistics Management. 2016.

[8] Basheka, Mugabira. Measuring professionalism variables and their implication to procurement outcomes in Uganda. 3rd International Procurement Conference Proceedings. 2008.

[9] Basheka BC. Procurement Planning and Accountability of Local Government Procurement Systems in Developing Countries: Evidence from Uganda. Journal of Public Procurement. 2008.

[10] Bor J, Chepkworny J, Bonuke R. Employee perceived interference and professional ethics on non-compliance with public procurement regulations, evidence from Kenya. European Journal of Business and Management. 2015; $7(5)$.

[11] Chogo CK, Ibua M, Banafa A, Adem A. Factors affecting procurement law compliance in public secondary schools in Kenya (A case study of public secondary schools in Kwale County). Imperial Journal of Interdisciplinary Research. 2016; 2(11).

[12] DA. Ethical Considerations in Procurement Management and Its Effects on Public Procurement (Greater Accra Region, a Case Study in Accra Metropolis). 2015.

[13] Davis JM. Procurement practices influencing service delivery: A case of Kenya power. European Journal of Logistics Purchasing and Supply Chain Management. 2014; 2(3): 79-137.

[14] Denison, Daniel R. Corporate culture and organizational effectiveness, Wiley. 1990.

[15] Embeli JS, Iravo AM, Birarori EO, Wamalwa RW. Factors affecting the use of public procurement and disposal Act of 2005 in public secondary schools - A survey study of Trans-Nzoia County in Kenya. International Journal of Recent Research in Commerce Economics and Management. 2014; 1(3): 29-38.

[16] Etikan I, Musa SA, Alkassim RS. Comparison Of Convenience Sampling And Purposive Sampling. American Journal Of Theoretical. 2016.

[17] Eyaa S, Oluka NP. Explaining non-compliance in public procurement in Uganda. International Journal of Business and Social Science. 2011; 2(11): 35-44.

[18] Fakhar et al. Impact of Organisational Culture on Organisational Performance: An over View. Interdisciplinary Journal of Contemporary Research in Business. 2012; 3(9): 975-985.

[19] Fink A, Litwin MS. How to measure survey reliability and validity. - books.google.com. 1995.

[20] Frempong RK, Bempah GO. An Assessment Of the Impact Of the Public Procurement Act 663 (2003) Of the Republic Of Ghana, Approaching a Decade Of Its Enactment. Politics and Law. 2013.

[21] Gelderman GPW, Brugman MJ. Public procurement and EU tendering directives - Explaining Non-Compliance. International Journal of Public Sector Management. 2006; 19(7): 702 - 714.

[22] Gesuka DM, Namusonge GS. Factors affecting compliance of public procurement regulations in Kenya: A case study of Butere District. International Journal of Social Sciences and Entrepreneurship. 2013; 1(5): 882-896.

[23] HS. Assessing the Level of Compliance of the Public Procurement ACT 2003 (ACT 663) In Public Institutions: a Case Study of Koforidua Polytechnic-Ghana. 2015.

[24] Hair JF, Black WC, Babin BJ, Anderson RE, Tatham RL. Multivariate data analysis. 2006; 6.

[25] Hui W, Othman R, Normah O, Rahman R, Haron N. Procurement issues in Malaysia. Int. J. Public Sector Manage. 2011; 24(6): 567-593.

[26] Imran R, Saeed T, Anis-Ul-Haq M, Fatima A. Organisational Climate as a Predictor of Innovative Work Behavior. African Journal of Business Management. 2010; 4(15): 3337-3343.

[27] Jennings DF, Young DM. An Empirical Comparison Between Objective And Subjective Measures Of the Product Innovation Domain Of Corporate Entrepreneurship. Journal Entrepreneurship Theory. 1990. 
[28] Jibrin SM, Ejura BS, Augustine IN. The public procurement reforms in Nigeria: Implementation and compliance challenges. Journal of Asian Business Strategy. 2014; 4(11): 149-162.

[29] Kiama PG. Factors affecting implementation of public procurement act in SACCO societies in Kenya. International Journal of Academic Research in Business and Social Sciences. 2014; 4(2): 169-194.

[30] Kibet Y, Metto N. Influence of organisation culture on the implementation of public procurement strategic plan. International Journal of Engineering and Management Invention. 2016; 01(02): 88-97.

[31] Kipchilat GT. An Evaluation of the Impact of the Public Procurement Regulations on Procurement in Kenyan Public Universities. Unpublished MBA Project. Egerton University, Nakuru Kenya. 2006.

[32] Lisa I. Compliance cultures A conceptual framework. Journal of management and organization. 2010; 19(7): 702714.

[33] Lodhia SK, Burritt RL. Public sector accountability failure in an emerging economy: The case of the National Bank of Fiji. International Journal of Public Sector Management. 2004; 17(4): 345-359.

[34] Mbago M, Ntayi JM, Muhwezi M. Compliance to acts, rules and regulations: Evidence from Sub-Saharan Africa, Journal of Public Procurement. 2016; 16(3): 374-405.

[35] McGlonn-Nelson K. Looking outward: exploring the intersections of sociocultural theory and gifted education. Journal of Advanced Academics. 2005; 17(1): 48-55.

[36] Mutinda, Paul. Determinants of public procurement procedure implementation in universities: A case of public universities in Kiambu County, Kenya. 2015.

[37] Narayana A. Critical Review of Organizational Culture on Employee Performance. American Journal of Engineering and Technology Management. 2017; 2(5): 72-76.

[38] Nelson DL, Quick JC. Understanding organisational behavior. Belmont, CA: Cengage South-Western. 2011.

[39] Nongo DS. The Impact of Organisational Culture on Corporate Effectiveness of the Cement Manufacturing Industry in Nigeria. International Journal of Business and Management Tomorrow. 2012; 2(2): 1-9.

[40] Nongo ES, Ikyanyon DN. The Influence of Corporate Culture on Employee Commitment to the Organization. International Journal of Business and Management. 2012; 7(22): 21-28.

[41] Obasan KA. Organisational culture and its corporate image: A model juxtaposition. Business and Management Research. 2012; 1(1).

[42] Obeng AF. Compliance with the Public Procurement Act 2003 (Act 663) _a Case Study of Selected Second Cycle Educational Institutions in the Ashanti Region of Ghana. 2016.

[43] Odhiambo W, Kamau P. Public Procurement: Lessons from Kenya, Tanzania and Uganda, OECD Development Centre Working Papers 208, OECD Publishing. 2013.

[44] Omagbon P. An assessment of compliance with the public procurement act by Nigerian local government. Journal of Accounting and Financial Management. 2016; 2(4): 1-11.

[45] Onyinkwa J, Ondieki MW, Omai MK. Factors influencing compliance to procurement regulations in public secondary schools in Kenya: A case of Nyamache district, Kissi county. Interdisciplinary Journal of Contemporary Research in Business. 2013; 5(1).

[46] Owoyemi O, Ekwoaba JO. Organisational Culture: A Tool for Management to Control, Motivate and Enhance Employees' Performance.. Ir.unilag.edu.ng. 2014.

[47] Pallant J. SPSS survival manual, McGraw-Hill Education (UK). 2007.

[48] Prier E, McCue CP. The Implications Of a Muddled Definition Of Public Procurement. Journal Of Public Procurement. 2009.

[49] Public Procurement Act, (Act 663), PPA Manual, September 2007.

[50] Raymond GA. The elements of strategic thinking. International Studies Review. 2008; 10: 315-317.

[51] Schein EH. 2nd ed, Organizational Culture and Leadership. San Francisco: Jossey-Bass. 2004.

[52] Schein EA. (n.d.). Organizational Socialization And the Profession Of Management. MIT Sloan management review. search.proquest.com. 
[53] Sun S. Organizational Culture And Its Themes. - International Journal Of Business And Management. 2008.

[54] Thai Khi V. Public Procurement Re-Examined. Journal of Public Procurement. 2001; 1(1): 9-50.

[55] Topalhan T, Gokce A, Kayipmaz AE. Research of the habit of seatbelt compliance of the employees of the Gazi university faculty of economics and administrative sciences. Biomedical Research. 2017; 28(4): 1615-1617.

[56] Tutu E0, Mensdar S, Ameya C. The Level of Compliance with the Public Procurement Act (Act 663) In Ghana. 2011.

[57] Tukamuhabwa RB. Antecedents and consequences of public procurement non-compliance behaviour. Journal of Economics and Behavioural Studies. 2015; 4(1): 34-46.

[58] Tuli F. The Basis Of Distinction Between Qualitative And Quantitative Research In Social Science: Reflection On Ontological, Epistemological And Methodological Perspectives. Ethiopian Journal Of Education And Sciences. 2010.

[59] United Nations Development Programme (UNDP): The Energy situation in developing countries, World Health Organization. 2007.

[60] Uyarra E, Flanagan K. Understanding the innovation impacts of public procurement, European Planning Studies. 2010; 18(1): 123-43.

[61] Walker H, Brammer S. Sustainable Procurement in the United Kingdom Public Sector, Supply Chain Management: An International Journal. 2009; 14(2): 128-37.

[62] Weeks R. Organizational Cultures. A contemporary management perspective, Acta Cpmmercii, 2010journals.com.za

[63] World Bank. Guidelines: Procurement under IBRD Loans and IDA Credits, World Bank, Washington, D.C. 1995.

[64] Zitha HE, Sebola MP, Mamabolo MA. Compliance to procurement processes, deviant behaviour and effects on service delivery in the public sector. Journal of Public Administration and Development Alternatives. 2016; 1. 